\title{
Determining the Financial Performance of Stock Market in India (With Special Reference to Derivatives)
}

\author{
S. Umamaheswari \\ Assistant Professor, Department of Commerce \\ Vellalar Educational Trust Institute of Arts and Science, Erode, Tamil Nadu, India \\ https://orcid.org/0000-0002-4838-5507
}

Manuscript ID:

COM-2021-09023821

Abstract

The innovative practices always persuade concerned people, whereas ideas and innovation become the hallmark of progress. Even the Stock market is also not exempted from this, whereas financial

Volume: 9 derivatives have given the drastic change in the growth of the financial market. The major reason behind introducing derivatives is for minimizing or eliminating price risk through hedging. The Derivatives market has shown tremendous growth in recent years and has become multi-trillion dollar market. Marked with the ability to partially and fully transfer the risk by locking in asset prices, derivatives gain popularity among investors.

Month: April

Year: 2021

E-ISSN: 2582-6190

Received: 11.12 .2020

Accepted: 13.03.2021

Published: 01.04.2021

Citation:

Umamaheswari, S.

"Determining the Financial

Performance of Stock

Market in India (With

Special Reference to

Derivatives)." ComFin

Research, vol. 9, no. 2,

2021, pp. 31-37.

DOI:

https://doi.org/10.34293/

commerce.v9i2.3821

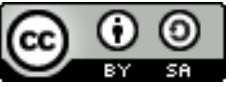

This work is licensed under a Creative Commons

Attribution-ShareAlike 4.0 International License

Keywords: BSE, CAGR, CD, Derivatives, F\&O, Hedging, MAR, MDD, NSE, SEBI

\section{Introduction}

The Derivatives market has shown tremendous growth in recent years and has become a multi-trillion dollar market. Marked with the ability to partially and fully transfer the risk by locking in asset prices, derivatives gain popularity among the investors. Derivatives are traded in organized stock exchanges or over the counter by derivative dealers. The impact of derivatives trading on stock market volatility has received considerable attention in recent years in India, particularly after the stock market crash of 2001. Derivative Products like Futures and Options on Indian Stock markets become important instruments of price discovery, Portfolio diversification and risk hedging in recent times. In the last decade, many emerging \& transition economies have started introducing derivative contracts. There is increasing sense that derivatives market plays a significant role in shaping growth of Stock market in India.

\section{Statement of the Problem}

New ideas \& innovations have always been the hallmark of progress made by humanity. At every stage of development, there have been two core factors that drive a man to ideas and innovation. These increasing return and reducing risk in all facets of life. The financial markets are no different. Hedging involves the transfer of market risk. Possibility of sustaining losses may occur due to unfavorable price changes. A derivatives transaction allows a firm to alter its market risk profile by transferring to counterparty some type of risk for a price. So hedging is prime reason for the existence of derivatives. After liberalization, derivatives are among the forefront innovations in the financial markets and it ensures an outlet of investors to protect from the vagaries. In India Derivative products serve as risk management tools by facilitating trading of risks among the market participants in the Stock Market. This study is an attempt to analyse the trading performance of financial derivatives in the Indian Stock market. 


\section{Objectives of the Study}

The main aim of this research paper is to study the trading performance of derivatives and to study a development pattern of the derivatives segment of trading in the Indian stock market.

- To measure the trading performance of derivative instruments turnover on Futures and Options (F\&O) segment in Bombay Stock Exchange (BSE) and National Stock Exchange (NSE).

- To analyse the derivative instruments turnover on Currency Derivative (CD) segment in Bombay Stock Exchange (BSE) and National Stock Exchange (NSE).

\section{Period of the Study}

The research study was confined for ten years from 2008-2009 to 2017-2018.

\section{Limitation of the Study}

The period of study is restricted to ten years. Data taken in the analysis is based on secondary data obtained from the source of BSE and NSE, the limitations of the BSE and NSE are also applicable to the research. Data has been recorded based on availability and hence in few instances up-to-date data has not been shown.

\section{Retrospective Study}

- Shalini, H., and Raveendra, P. (2014), encompassed "A study of derivatives and its current position in global financial derivatives market" examined trend \& growth and prospects and challenges of derivatives in Indian capital market finally concluded that there are significance and contribution of derivatives to the financial system.

- Sathya, S. (2015), Examined, "A comparative study on Equity, Commodity, Currency Derivatives in India - Evidence from Future market with special reference to BSE Ltd, Mumbai" and it is indicated that the contracts come in many forms, but the common ones include Option, Forwards / Futures and Swaps, finally concluded by that the result exhibits a currency returns are negatively correlated with Equity and Commodity
- Subbalakshmi, S. (2016) made an empirical study on derivative trading in India. The study preludes the emergence and growth of the derivatives market in recent phenomenon. The result attribute that advancement in the derivative market is in a gradient stage and Securities Board of India (SEBI) have to take certain steps for further development to attract more investors for derivative in Indian stock market.

\section{Profile of the Study}

The Government of India introduced the economic policy in 1991 to implement the structural reforms for reducing the economic imbalances in India. To structure the security market a regulatory authority named Securities and Exchange Board of India was introduced. A Stock market is a place where buyers and sellers of stock come together physically and virtually. The Indian stock market mainly functions of two major stock exchanges the Bombay Stock Exchange (BSE) and National Stock Exchange (NSE). The emergence and growth of the derivative instrument market are to protect the investors against uncertainties due to volatility in Asset prices. Hedging is the core factor for the existence of derivatives in the Indian Stock market. The trading of derivatives place a remarkable position for implementing various financial policies. The trading commenced in the Indian Stock market on BSE and NSE during 2000. There are four main types of a derivatives contract, they are Forwards, Futures \& Options and Swaps. Derivatives market contributes a tremendous growth in terms of volumes and contracts traded.

\section{Research Methodology}

The study conducted is based on descriptive research design, which means a description of the state of affairs as it exists at present. Secondary data for ten years has been obtained from the source of BSE and NSE websites besides other sources like books, journals, articles, newspapers and other websites. Analysis of the secondary data has been done both on a historical and quantitative basis. No sample has been chosen as the entire data provided has been included for the study. 
Tools and Techniques of the Study

The tools used in the study include Compound Annual Growth Rate (CAGR), Maximum Draw Down (MDD) and Measurement of return Adjusted for Risk (MAR) ratio. Hypothesis testing is also implemented to measure the trading performance of derivatives with the market turnover of the Cash segment and the Futures \& Options (F\&O) segment of Bombay Stock Exchange and the National Stock Exchange is compared.

\section{Hypothesis of the Study}

Testing of hypothesis is made to review the assumptions as the derivatives segment trading in Indian stock market is having a relationship with the Bombay Stock Exchange (BSE) and National Stock Exchange (NSE) is significant or not. Hence null hypothesis is formulated as:

H01: There is a relation in performance of market turnover in Currency Derivative (CD) segment at Bombay Stock Exchange (BSE) and National Stock Exchange (NSE).

H02: There is a relation in performance of market turnover in the Futures and Options segment in the Indian stock market.

\section{Analysis of Data and Interpretation}

Quantitative data analysis is used by adopting the statistical methods of Cumulative Annual Growth Rate (CAGR). The financial tools of Maximum Drawdown (MDD) and the Measures of return adjusted for risk (MAR) ratio also used in this study. Moreover testing of hypothesis is also framed to make a comparison of selected variables by using the technique of Analysis of Variance (ANOVA) and Regression Analysis. This Analysis part is segmented into three portions as

1. Performance of Derivatives in NSE

2. Performance of Derivatives in BSE and

3. Comparing F\&O and CD Segment in BSE And NSE

\section{Performance of Derivatives in NSE} Trade Volumes in F\&O Segment

\begin{tabular}{|c|c|c|c|}
\hline Tools & $\begin{array}{c}\text { Total No. of } \\
\text { Contracts }\end{array}$ & $\begin{array}{c}\text { Total } \\
\text { Turnover }\end{array}$ & $\begin{array}{c}\text { Average } \\
\text { Daily Turnover }\end{array}$ \\
\hline CAGR & 1.39 & 18.98 & 28.91 \\
\hline
\end{tabular}

\begin{tabular}{|c|c|c|c|}
\hline MDD & 68.67 & 88 & 92.11 \\
\hline MAR & 2.02 & 21.56 & 31.38 \\
\hline
\end{tabular}

Inference: The trade volumes in F\&O segment indicate that the maximum drawdown (92.11) is high, which represents that the trading volume of Futures and Options in derivative market has high volatile position. The average daily turnover of F\&O is favorable during the period of study.

Trade Volumes in CD Segment

\begin{tabular}{|c|c|c|c|}
\hline Tools & $\begin{array}{c}\text { Total No. of } \\
\text { Contracts }\end{array}$ & $\begin{array}{c}\text { Total } \\
\text { Turnover }\end{array}$ & $\begin{array}{c}\text { Average } \\
\text { Daily Turnover }\end{array}$ \\
\hline CAGR & 24.51 & 28.00 & 31.39 \\
\hline MDD & 96.64 & 96.92 & 94.62 \\
\hline MAR & 25.35 & 28.88 & 33.17 \\
\hline
\end{tabular}

Inference: The trading performance of the Currency Derivative segment reveals a positive trade volume. It indicates that Currency Derivatives trading has peak volatility, the value of Cumulative Annual Growth rate (CAGR) and Measures of return Adjusted for risk Ratio (MAR) lies at 31.39 and 33.17. Hence the trading performance of the Currency Derivative segment shows a positive trend.

Performance of Futures Turnover

\begin{tabular}{|c|c|c|c|}
\hline Tools & $\begin{array}{c}\text { Index Futures } \\
\text { Turnover }\end{array}$ & $\begin{array}{c}\text { Stock Futures } \\
\text { Turnover }\end{array}$ & $\begin{array}{c}\text { Total } \\
\text { Turnover }\end{array}$ \\
\hline CAGR & -6.43 & 6.37 & 1.63 \\
\hline MDD & 48.58 & 68.73 & 56.34 \\
\hline MAR & -13.23 & 9.26 & 2.89 \\
\hline
\end{tabular}

Inference: In Performance of Futures Turnover, Stock Futures Turnover is comparatively better than Index Futures Turnover. Even there is a moderate fluctuation; the Performance of Futures Turnover trading is risk.

Performance of Options Turnover

\begin{tabular}{|c|c|c|c|}
\hline Tools & $\begin{array}{c}\text { Index Options } \\
\text { Turnover }\end{array}$ & $\begin{array}{c}\text { Stock Options } \\
\text { Turnover }\end{array}$ & $\begin{array}{c}\text { Total } \\
\text { Turnover }\end{array}$ \\
\hline CAGR & 29.70 & 33.10 & 29.92 \\
\hline MDD & 94.87 & 96.24 & 94.98 \\
\hline MAR & 31.30 & 34.39 & 31.50 \\
\hline
\end{tabular}

Inference: The performance of Options Turnover in Derivative segment at National Stock Exchange states a positive impact between Index Options and Stock Options Turnover. The Maximum Draw Down 
(MDD) stands at 94.98 percentage, Cumulative Annual Growth Rate and Measures of return Adjusted for risk Ratio (MAR) yields a better return.

\section{Performance of Derivatives in BSE}

Derivatives Trade Volume at BSE

\begin{tabular}{|c|c|c|c|}
\hline Tools & $\begin{array}{c}\text { Total No. of } \\
\text { Contracts }\end{array}$ & $\begin{array}{c}\text { Total } \\
\text { Turnover }\end{array}$ & $\begin{array}{c}\text { Average Daily } \\
\text { Turnover }\end{array}$ \\
\hline CAGR & -21.43 & -12.09 & -4.58 \\
\hline MDD & 99.99 & 99.99 & 99.99 \\
\hline MAR & -21.43 & -12.09 & -4.58 \\
\hline
\end{tabular}

Inference: Derivatives trade volume in Bombay Stock Exchange reflects a negative sign during the entire period of study. The Maximum Draw Down (MDD) viewed a high volatile position which indicates 99.99 percentage and the same value of -4.58 of Cumulative Annual Growth Rate (CAGR) and Measures of return Adjusted for risk Ratio (MAR).It is inferred that derivatives trade volume is not up to the level of trading performance in the National Stock Exchange.

Performance of Index and Equity Futures Contract

\begin{tabular}{|c|c|c|c|}
\hline Tools & $\begin{array}{c}\text { Index } \\
\text { Futures } \\
\text { Contract }\end{array}$ & $\begin{array}{c}\text { Equity } \\
\text { Futures } \\
\text { Contract }\end{array}$ & $\begin{array}{c}\text { Total } \\
\text { Contract }\end{array}$ \\
\hline CAGR & -21.49 & -1.57 & -21.45 \\
\hline MDD & 99.94 & 99.99 & 99.94 \\
\hline MAR & -21.50 & -1.57 & -21.45 \\
\hline
\end{tabular}

Inference: The performance of the Index and Equity Futures contract represents an unfavourable condition. The total contract of Index and Equity futures contract lies at the value as -21.45. It is observed and stated that the value of an investment over years is riskyard.

\section{Performance of Index and Equity Futures}

Turnover

\begin{tabular}{|c|c|c|c|}
\hline Tools & $\begin{array}{c}\text { Index } \\
\text { Futures } \\
\text { Turnover }\end{array}$ & $\begin{array}{c}\text { Equity } \\
\text { Futures } \\
\text { Turnover }\end{array}$ & $\begin{array}{c}\text { Total } \\
\text { Turnover }\end{array}$ \\
\hline CAGR & -30.11 & 9.11 & -44.54 \\
\hline MDD & 99.94 & 99.99 & 99.99 \\
\hline MAR & -30.12 & 9.11 & -44.54 \\
\hline
\end{tabular}

Inference: It is interpreted that the total turnover for Index Futures and Equity Futures Turnover of Cumulative Annual Growth Rate (CAGR) and the Measures of return adjusted for risk Ratio (MAR) lies at the value of -44.54 . Hence the trading performance of Index Futures and Equity Futures Turnover is not held good condition during the study period.

\section{Hypothesis Testing}

H01: There is a significant relationship between Futures and Options (F\&O) in derivatives at the Bombay Stock Exchange (BSE) and National Stock Exchange (NSE).

H02: There is a significant relationship between Currency Derivative (CD) segment in Bombay Stock Exchange (BSE) and the National Stock exchange (NSE).

\section{Comparing F\&O and CD Segment in BSE and NSE}

Regression Analysis Output on Market Turnover in Cash Segment of BSE \& NSE

\section{Regression Statistic}

\begin{tabular}{|c|c|c|c|c|}
\hline \multicolumn{5}{|c|}{ Model Summary } \\
\hline Model & $\mathbf{R}$ & $\begin{array}{c}\mathbf{R} \\
\text { Square }\end{array}$ & $\begin{array}{c}\text { Adjusted R } \\
\text { Square }\end{array}$ & $\begin{array}{c}\text { Std. Error } \\
\text { of the } \\
\text { Estimate }\end{array}$ \\
\hline 1 & $.975^{\mathrm{a}}$ & .950 & .936 & .765 \\
\hline
\end{tabular}

Anova for the Market Turnover in Cash Segment of BSE and NSE

\begin{tabular}{|c|c|c|c|c|c|}
\hline Model & $\begin{array}{c}\text { Sum of } \\
\text { Squares }\end{array}$ & d.f & $\begin{array}{c}\text { Mean } \\
\text { Square }\end{array}$ & F & Sig. \\
\hline Regression & 78.403 & 2 & 39.202 & 66.986 & $.000^{\mathrm{b}}$ \\
\hline Residual & 4.097 & 7 & .585 & & \\
\hline Total & 82.500 & 9 & & & \\
\hline
\end{tabular}




\begin{tabular}{|c|c|c|c|c|c|}
\hline \multicolumn{2}{|c}{ Regression Coefficients of Market Turnover in Cash Segment at BSE and NSE } \\
\begin{tabular}{|c|c|c|c|c|c|}
\hline \multirow{2}{*}{ Model } & Unstandardized Coefficients & Standardized Coefficients & \multirow{2}{*}{ t } \\
\cline { 2 - 6 } & B & Std. Error & Beta & & \\
\hline (Constant) & 2010.142 & 1.393 & & -1442.764 & .000 \\
\hline BSE Cash Segment & .000 & .000 & .853 & -10.032 & .000 \\
\hline NSE Cash Segment & $3.353 \mathrm{E}-5$ & .000 & .605 & 7.118 & .000 \\
\hline
\end{tabular}
\end{tabular}

Inference: The Market turnover in the cash segment of the Bombay Stock Exchange (BSE) and National Stock Exchange (NSE) is compared by using the Regression Analysis. The market turnover of the cash segment in the Bombay Stock Exchange (BSE) is having a significant impact on trading with the market turnover of the cash segment in the National Stock Exchange (NSE).

It is interpreted in regression statistics to measure the "goodness of fit" in it. The multiple $\mathrm{R}$ indicates the correlation coefficient of both the Bombay Stock Exchange (BSE) and National Stock Exchange (NSE). The table value of R is 0.975 , which means there is a strong relationship between them. The value of R Square shows 0.950 as the coefficient of determination. It represents 0.950 points that fall on the regression line and the standard error of the estimated value lies at 0.765 .

ANOVA for the market turnover in the cash segment of the Bombay Stock Exchange (BSE) and National Stock Exchange (NSE) indicates the F value as a null hypothesis and the result ends with significant. The regression coefficient of market turnover in the cash segment at the Bombay Stock Exchange (BSE) and National Stock Exchange (NSE) is significant.
Hence the trading performance of market turnover in the cash segment of Bombay Stock Exchange (BSE) and National Stock Exchange (NSE) has a significant relationship. It is proved by the result that viewed the performance of market turnover traded in cash segment at National Stock Exchange (NSE) is having an impact on market turnover traded in cash segment at Bombay Stock Exchange (BSE) and viceversa.

Regression Analysis Output on Market Turnover in Futures and Options Segment at BSE \& NSE Regression Statistics

\begin{tabular}{|c|c|c|c|c|}
\hline \multicolumn{5}{|c|}{ Model Summary } \\
\hline Model & $\mathbf{R}$ & $\begin{array}{c}\mathbf{R} \\
\text { Square }\end{array}$ & $\begin{array}{c}\text { Adjusted } \\
\text { R Square }\end{array}$ & $\begin{array}{c}\text { Std. Error of } \\
\text { the Estimate }\end{array}$ \\
\hline 1 & $.574^{\mathrm{a}}$ & .330 & .138 & 2.811 \\
\hline
\end{tabular}

Anova for the Market Turnover in Futures and Options Segment at BSE and NSE

\begin{tabular}{|c|c|c|c|c|c|}
\hline Model & $\begin{array}{c}\text { Sum of } \\
\text { Squares }\end{array}$ & df & $\begin{array}{c}\text { Mean } \\
\text { Square }\end{array}$ & F & Sig. \\
\hline Regression & 27.184 & 2 & 13.592 & 1.720 & $.247^{\mathrm{b}}$ \\
\hline Residual & 55.316 & 7 & 7.902 & & \\
\hline Total & 82.500 & 9 & & & \\
\hline
\end{tabular}

\section{Regression Coefficients of Market Turnover in Futures and Options Segment at BSE and NSE}

\begin{tabular}{|c|c|c|c|c|c|}
\hline \multirow{2}{*}{ Model } & \multicolumn{2}{|c|}{ Unstandardized Coefficients } & Standardized Coefficients & \multirow{2}{*}{ t } & \multirow{2}{*}{ Sig. } \\
\cline { 2 - 6 } & B & Std. Error & Beta & 996.354 & .000 \\
\hline (Constant) & 2011.841 & 2.019 & & 1.186 & .274 \\
\hline F\&O IN NSE & $6.673 \mathrm{E}-7$ & .000 & .368 & -1.322 & .228 \\
\hline F\&O IN BSE & $-1.375 \mathrm{E}-6$ & .000 & -.411 & & \\
\hline
\end{tabular}

Inference: The market turnover in the Futures and Options (F\&O) segment of the Bombay Stock Exchange (BSE) and National Stock Exchange (NSE) is compared with a statistical tool of Regression analysis.

Regression Statistic value represents the multiple $\mathrm{R}$ as 0.574 as a linear relationship between the
Bombay Stock Exchange (BSE) and National Stock Exchange (NSE). The value of R Square is 0.330 as the coefficient of determination. The adjusted value of $\mathrm{R}$ square as 0.138 points fall on the regression line and the standard error of estimate value lies at 2.811.

The ANOVA for comparing a significant relationship between Bombay Stock Exchange 
(BSE) and National Stock Exchange (NSE) in trading performance of the market turnover in Futures and Options (F\&O) segment holds the value of 0.247 and a result confined that there is no significant relationship prevailed in trading with market turnover of Futures and Options (F\&O) segment in Bombay Stock Exchange (BSE) and National Stock Exchange (NSE).

The regression coefficient of market turnover in the Futures and Options (F\&O) segment at Bombay Stock Exchange (BSE) lies at 0.228 and in the case of the National Stock Exchange (NSE) lies at 0.274 as the value. So it represents that there is no significant regression between the Bombay Stock Exchange (BSE) and National Stock Exchange (NSE) in trading with the market turnover of Futures and Options (F\&O) segment.

Hence the regression analysis reveals the end result on the trading of market turnover of Futures and Options (F\&O) segment at National Stock Exchange (NSE) is not having any impact on the trading of market turnover in Futures and Options (F\&O) segment at Bombay Stock Exchange (BSE).

\section{Performance of Index Futures and Equity Futures Turnover at BSE}

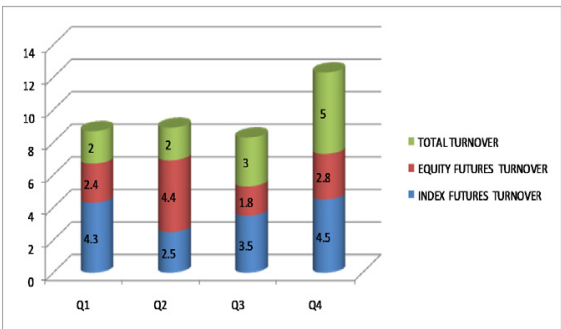

\section{Performance of Market Turnover in Futures and} Options Segment at BSE and NSE

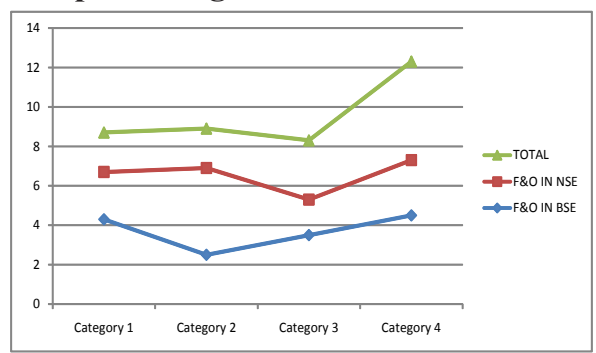

\section{Summary of Findings}

1. Derivative Trading Performance at NSE

- Currency Derivatives trade volume indicates a high risk on investment.

- The trading performance of Futures and Options contract reveals a favorable position.

- The options turnover yield positive growth during the entire period of study.

- The stock futures turnover is better than Index futures turnover.

- Number of securities traded \& Market capitalization holds good result.

\section{Derivative Trading Performance at BSE}

- Interest rate derivatives reflect positive sign during the entire period of study.

- Performance of Equity turnover reflects a negative impact due to volatility.

- Call contract better than put contract.

- Equity Futures turnover is better than Index Futures turnover.

- Equity options revealed positive growth.

\section{Comparison of Derivative Segment at BSE and} NSE

- Futures and Options trading in both BSE and NSE holds a good result.

- There is a significant relationship between the trading of cash segment in BSE and NSE.

- There is no significant relationship between the trading of Futures and Options Segment at BSE and NSE.

- The trading performance of NSE is better than BSE.

\section{Suggestions}

BSE has to follow risk management tools and strategies for protecting the interest of investors.

Derivatives market should require more resources to develop the business process and technology for derivative trading in India.

\section{Conclusion}

Derivative trading is performed well deserved and played a significant role among all the financial products. India's experience with the launch of the derivatives market has been extremely encouraging 
and successful. The futures and Options segment is acted as lucrative for derivative trading in the Indian Stock market.

\section{Scope for Further Research}

There is still the same procedure that can be applied to do further research in the area of derivatives where this study not includes the commodity derivatives and Foreign Exchange (FOREX) derivatives or even this research study can also be further expanded by implementing Autoregressive Conditional Heteroscedastic (ARCH) or Generalised Autoregressive Conditional Heteroscedastic model.

\section{References}

Avadhani, V.A. Security Analysis and Portfolio Management. Himalaya Publishing House, 2016.

Bandivadekar, Snehal, and Saurabh Ghosh. "Derivatives and Volatility on Indian Stock Markets." RBI Occasional Papers, vol. 24, no. 3, 2003, pp. 188-201.

Bhole, L.M. Financial Institutions and Markets: Structure, Growth and Innovation. Tata McGraw Hill Education, 2004.

Gupta, S.P. Statistical Methods. Sultan Chand \& Sons, 2014.

Gurusamy, S. Capital Markets. Vijay Nicole Imprints, 2008.

Kamaraj, K., and Mahalakshmi, V. "Financial Performance Analysis of IPO's (Selected Companies) - National Stock Exchange
Market." Shanlax International Journal of Commerce, vol. 7, no. 1, 2019, pp. 12-18.

Manjushree, S. "A Derivative is a Risk Hedging Tool from Investor Perspective." Shanlax International Journal of Commerce, vol. 8, no. 3, 2020, pp. 39-44.

Padhi, Prabina Kumar. "Derivative Trading in Indian Capital Market: An Empirical Study of NSE." Pacific Business Review International, vol. 8, no. 2, 2015, pp. 89-94.

Raghavan, S.T.P., and Aravind Singh Tomar. "Derivatives Market in India: An Empirical Analysis on Perception of Retail Investors towards Derivatives Market with Reference to Visakhapatnam District." Journal of Advances and Scholarly Researches in Allied Education, vol. 12, no. 2, 2017, pp. 214-218.

Singh, Gurcharan, and Salony Kansal. "Impact of Derivative Trading on Stock Market Volatility during Pre and Post F\&O Period: A Case Study of NSE." Management Convergence, vol. 1, no. 1, 2010.

Shetty, Chetan, and Anitha S. Yadav. "Impact of FinancialRisks on the Profitability of Commercial Banks in India." Shanlax International Journal of Management, vol. 7, no. 1, 2019, pp. 25-35.

Vashistha, Ashutosh, and Satish Kumar. "Development of Financial Derivatives Market in India - A Case Study." International Research Journal of Finance and Economics, no. 37, 2010, pp. 15-29.

\section{Author Details}

Dr. S. Umamaheswari, Assistant Professor, Department of Commerce, Vellalar Educational Trust Institute of Arts and Science, Erode, Tamil Nadu, India, Email ID: umamaheshwari@vetias.ac.in. 